\title{
Effect of Pressure and Temperature Upon the Optical Dispersion of Benzene, Carbon Tetrachloride and Water
}

\author{
R. M. Waxler, C. E. Weir, and H. W. Schamp, Jr.
}

(May 26, 1964)

\begin{abstract}
An interferometer has been used to measure the change in index of refraction with change in pressure or temperature. Absolute indices of refraction are reported to five decimals for benzene, carbon tetrachloride, and water at eight different wavelengths in the visible region of the spectrum at pressures as high as 1100 bars and temperatures as high as $55{ }^{\circ} \mathrm{C}$. The data for benzene and carbon tetrachloride have been fitted to one term, dispersion equations of the Drude and Lorentz-Lorenz types. The observed changes in index of refraction for these two liquids have been attributed to change in density plus a shift in the fundamental absorption frequency, assuming that the oscillator strength remains constant. The data for water have been treated and explained in the same manner but with the additional postulate that water consists of two different molecular types.
\end{abstract}

\section{Introduction}

An interferometric technique has been described for use in precision measurements of index of refraction of liquids at pressures as high as 1100 bars in the range $0{ }^{\circ} \mathrm{C}$ to $55^{\circ} \mathrm{C}$ by observing the shift in interference fringes as pressure and temperature are varied [1]. ${ }^{1}$ Data reported on the indices of benzene, carbon tetrachloride, and water at one wavelength were of such a nature as to warrant additional study of the effect of pressure and temperature upon the optical dispersion of these liquids. The present report describes the modifications of the instrument to permit simultaneous observation of the shift in interference fringes for eight spectral lines spaced to permit calculation of the change in index throughout the visible range of the spectrum. Data on indices for the three liquids, benzene, carbon tetrachloride, and water are reported and some of the implications of the results are discussed.

\section{Experimental Method}

The general experimental method has been described fully [1] and will be outlined only briefly here. It consists of placing an interferometer containing the liquid of interest inside a high pressure vessel equipped with glass windows. The shift in interference fringes is recorded photographically as the pressure is decreased from an elevated value to 1 bar. The refractive index is calculated from the relationship

$$
\Delta \mu=\Delta n \lambda / 2 t \sin \theta
$$

where $\Delta \mu$ is the change in refractive index; $\Delta n$, the number of fringes passing a reference point during the pressure change; $\lambda$, the wavelength of the light employed; $t$, the distance between the optical flats; and $\theta$, the angle of incidence of light which, in these experiments, was $90^{\circ}$.

${ }^{1}$ Figures in brackets indicate the literature references at the end of this paper
In the interferograph developed by Saunders [2], light from the discharge tube is dispersed into its component spectral lines by a prism. Ordinarily all lines except the one in use are reflected by a mirror while the desired line passes through a slit in the mirror and is detected photographically. By rotating the camera through $90^{\circ}$ and inserting a stop about $3 \mathrm{~mm}$ in width at the object position, several small images, one for each spectral line, are permitted to fall on the slit in the mirror and thus be detected by the film. The stop restricts the width of each line image and prevents overlapping. Thus each spectral line produces its own system of interference fringes, these systems being displaced vertically on the film. Each set of fringes will move as the pressure is varied, and a permanent record of the fringe shift is obtained on the film. The number of fringes can then be counted at leisure after the film is developed.

Using extremely high speed film it was found that the helium lines, 6678.15, 5875.62, 5015.68, and $4921.93 \AA$ could be photographed successfully. To obtain additional lines a cadmium lamp was placed directly behind the helium tube and cadmium lines at $6438.47,5085.82,4799.92$, and $4678.16 \AA$ were also used. With the high speed film, it was found necessary to perform all experiments in a dark room to cut down the effects of extraneous light. It was also essential to shield the camera from the light emanating from the discharge tubes. Because of the great intensity of the helium yellow line at $5875.62 \AA$, a small filter was placed at the exit slit of the mirror where this radiation fell on the photographic film. A typical photographic record is shown in figure 1.

As shown by eq (1) only the changes in refractive index were measured, the initial indices at one bar were obtained from published data for benzene [3] and water [4]. Data of the required precision do not appear to be available for carbon tetrachloride, and its index was measured by the method of minimum deviation, the liquid being enclosed in a hollow glass prism [4]. 


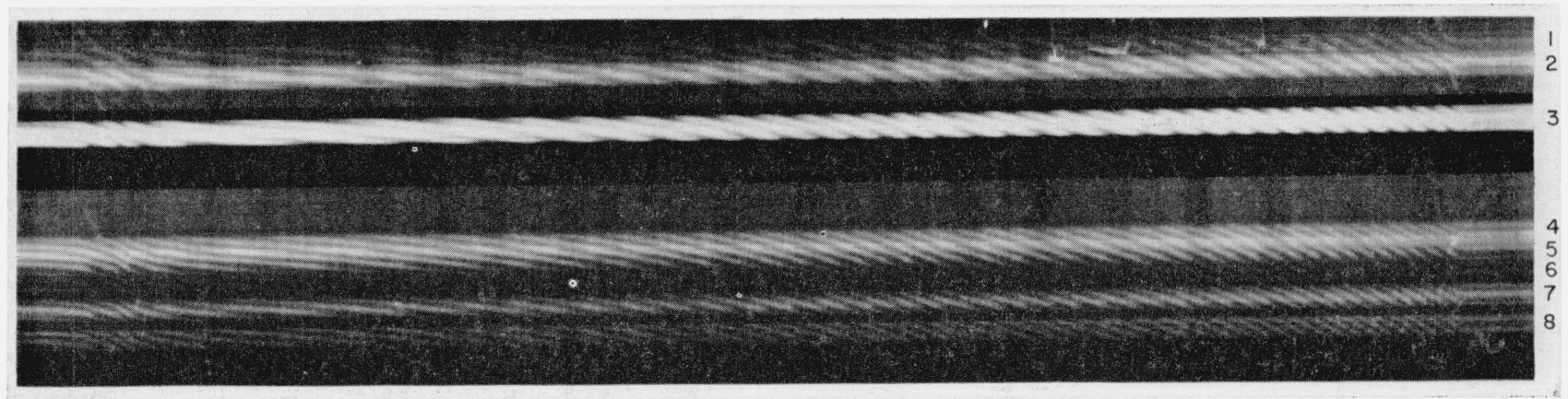

Figure 1. Photograph of the shift in interference fringes for water from an elevated piessure to one atmosphere at constant temperature.

Fringe shifts for eight spectral lines are shown: (1) A faint line, helium red of $6678.15 \AA$; (2) a strong line, cadium red of $6438.47 \AA$; (3) a very strong line, helium yellow of $5875.62 \AA$; (4), (5) two strong lines closely adjacent to each other, cadium green of $5085.82 \AA$ and helium green of $5015.68 \AA$; (6) a very faint line, helium blue-green of $4921.93 \AA$; (7) a strong line, cadium blue of $4799.92 \AA$; (8) a strong line, cadium violet of $4678.16 \AA$.

\section{Experimental Results}

The experimental data for refractive index are given in tables 1,2 , and 3 as a function of pressure, temperature, and wavelength. It should be noted that the indices reported are absolute values. From previous experiments it has been found that the standard deviation of the index values is 0.00005 which corresponds to a limit of reproducibility of $\pm 0.0001[1]$.

TABLE 1. Absolute refractive index of benzene as a function of pressure, temperature, and wavelength

\begin{tabular}{|c|c|c|c|c|c|c|c|c|c|c|}
\hline $\begin{array}{l}\text { Temper- } \\
\text { ature }\end{array}$ & $\underset{\text { bars }}{\text { Pressure }}$ & 6678.149 & 6438.4696 & 5875.618 & 5085.82 & 5015.675 & 4921.929 & 4799.92 & 4678.16 & $\begin{array}{l}\text { Specific } \\
\text { volume }\end{array}$ \\
\hline $\begin{array}{c}{ }^{\circ} \mathrm{C} \\
24.80\end{array}$ & $\begin{array}{c}1 \\
250.1 \\
489.0 \\
666.1\end{array}$ & $\begin{array}{l}1.49316 \\
1.50465 \\
1.51413 \\
1.52021\end{array}$ & $\begin{array}{l}1.49455 \\
1.50616 \\
1.51561 \\
1.52168\end{array}$ & $\begin{array}{l}1.49859 \\
1.51031 \\
1.51982 \\
1.52593\end{array}$ & $\begin{array}{l}1.50704 \\
1.51891 \\
\text { 1. } 52873 \\
1.53488\end{array}$ & $\begin{array}{l}\text { 1. } 50802 \\
1.51995 \\
1.52969 \\
1.53593\end{array}$ & $\begin{array}{l}1.50941 \\
1.52139 \\
1.53113 \\
1.53743\end{array}$ & $\begin{array}{l}1.51137 \\
1.52338 \\
1.53320 \\
1.53952\end{array}$ & $\begin{array}{l}1.51350 \\
1.52557 \\
1.52544 \\
\text { 1. } 54180\end{array}$ & $\begin{array}{c}\mathrm{ml} / \mathrm{g} \\
1.14433 \\
1.11973 \\
1.10057 \\
1.08828\end{array}$ \\
\hline 34.50 & $\begin{array}{r}1 \\
246.2 \\
484.8 \\
757.2 \\
1107.7\end{array}$ & $\begin{array}{l}1.48684 \\
1.49879 \\
1.50882 \\
1.51844 \\
1.52903\end{array}$ & $\begin{array}{l}1.48822 \\
1.50025 \\
1.51029 \\
1.51991 \\
1.53052\end{array}$ & $\begin{array}{l}1.49221 \\
1.50438 \\
1.51445 \\
1.52418 \\
1.53489\end{array}$ & $\begin{array}{l}1.50050 \\
1.51286 \\
1.52316 \\
1.53305 \\
1.54401\end{array}$ & $\begin{array}{l}1.50151 \\
1.51391 \\
1.52421 \\
1.53415 \\
1.54514\end{array}$ & $\begin{array}{l}1.50284 \\
1.51532 \\
1.52557 \\
1.53555 \\
1.54657\end{array}$ & $\begin{array}{l}1.50477 \\
1.51724 \\
1.52762 \\
1.53761 \\
1.54867\end{array}$ & $\begin{array}{l}\text { 1. } 50690 \\
1.51946 \\
1.52986 \\
1.53992 \\
1.55102\end{array}$ & $\begin{array}{l}1.15805 \\
1.13187 \\
1.11138 \\
1.09192 \\
1.07112\end{array}$ \\
\hline 54.34 & $\begin{array}{r}1 \\
274.5 \\
484.4 \\
770.2 \\
1124.5\end{array}$ & $\begin{array}{l}1.47390 \\
1.48888 \\
1.49832 \\
1.50913 \\
1.52059\end{array}$ & $\begin{array}{l}1.47521 \\
1.49016 \\
1.49972 \\
1.51060 \\
1.52202\end{array}$ & $\begin{array}{l}1.47910 \\
1.49422 \\
1.50382 \\
1.51478 \\
1.52633\end{array}$ & $\begin{array}{l}1.48729 \\
1.50271 \\
1.51251 \\
1.52362 \\
1.53546\end{array}$ & $\begin{array}{l}1.48817 \\
1.50361 \\
1.51340 \\
1.52460 \\
1.53644\end{array}$ & $\begin{array}{l}1.48949 \\
1.50498 \\
1.51483 \\
1.52606 \\
1.53790\end{array}$ & $\begin{array}{l}1.49128 \\
1.50681 \\
1.51672 \\
1.52798 \\
1.53988\end{array}$ & $\begin{array}{l}1.49334 \\
1.50894 \\
1.51889 \\
1.53018 \\
1.54214\end{array}$ & $\begin{array}{l}1.18757 \\
1.15350 \\
1.13305 \\
1.11014 \\
1.08705\end{array}$ \\
\hline
\end{tabular}

TABLE 2. Absolute refractive index of carbon tetrachloride as a function of pressure, temperature, and wavelength

\begin{tabular}{|c|c|c|c|c|c|c|c|c|c|c|}
\hline $\begin{array}{l}\text { Temper- } \\
\text { ature }\end{array}$ & Pressure Wavelength & 6678.149 & 6438.4696 & 5875.618 & 5085.82 & 5015.675 & 4921.929 & 4799.92 & 4678.16 & $\begin{array}{l}\text { Specific } \\
\text { volume }\end{array}$ \\
\hline $\begin{array}{c}{ }^{\circ} \mathrm{C} \\
24.80\end{array}$ & $\begin{array}{r}1 \\
276.9 \\
523.6 \\
797.4 \\
1116.7\end{array}$ & $\begin{array}{l}1.45476 \\
1.46762 \\
1.47706 \\
1.48599 \\
1.49502\end{array}$ & $\begin{array}{l}1.45556 \\
1.46846 \\
1.47790 \\
1.48683 \\
1.49591\end{array}$ & $\begin{array}{l}1.45791 \\
1.47089 \\
1.48037 \\
1.48934 \\
1.49847\end{array}$ & $\begin{array}{l}1.46270 \\
1.47583 \\
1.48542 \\
1.49404 \\
1.50371\end{array}$ & $\begin{array}{l}1.46322 \\
1.47635 \\
1.48598 \\
1.49509 \\
1.50429\end{array}$ & $\begin{array}{l}1.46400 \\
1.47721 \\
1.48674 \\
1.49591 \\
1.50515\end{array}$ & $\begin{array}{l}1.46511 \\
1.47831 \\
1.48794 \\
1.49712 \\
1.50639\end{array}$ & $\begin{array}{l}1.46626 \\
1.47951 \\
1.48917 \\
1.49835 \\
1.50767\end{array}$ & $\begin{array}{c}m l / g \\
0.630927 \\
.614859 \\
.603465 \\
.592991 \\
.582760\end{array}$ \\
\hline 34.50 & $\begin{array}{r}1 \\
255.4 \\
480.9 \\
756.1 \\
1119.9\end{array}$ & $\begin{array}{l}1.44890 \\
1.46164 \\
1.47102 \\
1.48045 \\
1.49098\end{array}$ & $\begin{array}{l}\text { 1. } 44965 \\
1.46243 \\
1.47182 \\
1.48130 \\
1.49186\end{array}$ & $\begin{array}{l}1.45197 \\
1.46481 \\
1.47426 \\
1.48381 \\
1.49441\end{array}$ & $\begin{array}{l}1.45675 \\
1.46975 \\
1.47928 \\
1.48896 \\
1.49973\end{array}$ & $\begin{array}{l}1.45723 \\
1.47022 \\
1.47980 \\
1.48949 \\
1.50028\end{array}$ & $\begin{array}{l}1.45802 \\
1.47104 \\
1.48059 \\
\text { 1. } 49031 \\
1.50109\end{array}$ & $\begin{array}{l}1.45908 \\
1.47214 \\
1.48172 \\
1.49146 \\
1.50229\end{array}$ & $\begin{array}{l}1.46020 \\
1.47329 \\
1.48292 \\
1.49271 \\
1.50360\end{array}$ & $\begin{array}{l}.638553 \\
.622336 \\
.610937 \\
.599476 \\
.587098\end{array}$ \\
\hline 54.34 & $\begin{array}{r}1 \\
248.7 \\
452.7 \\
751.9 \\
1059.2\end{array}$ & $\begin{array}{l}1.43763 \\
1.45181 \\
1.46107 \\
1.47281 \\
1.48280\end{array}$ & $\begin{array}{l}1.43844 \\
1.45266 \\
1.46193 \\
1.47371 \\
1.48371\end{array}$ & $\begin{array}{l}1.44067 \\
1.45493 \\
1.46428 \\
1.47616 \\
1.48617\end{array}$ & $\begin{array}{l}1.44534 \\
1.45978 \\
1.46924 \\
1.48118 \\
1.49135\end{array}$ & $\begin{array}{l}1.44581 \\
1.46025 \\
1.46975 \\
1.48172 \\
1.49190\end{array}$ & $\begin{array}{l}1.44663 \\
1.46110 \\
1.47059 \\
1.48257 \\
1.49281\end{array}$ & $\begin{array}{l}1.44774 \\
1.46225 \\
1.47176 \\
1.48376 \\
1.49402\end{array}$ & $\begin{array}{l}1.44879 \\
1.46335 \\
1.47289 \\
1.48497 \\
1.49520\end{array}$ & $\begin{array}{r}.654959 \\
.636227 \\
.624227 \\
.610060 \\
.598302\end{array}$ \\
\hline
\end{tabular}


TABLE 3. Absolute refractive index of water as a function of pressure, temperature, and wavelength

\begin{tabular}{|c|c|c|c|c|c|c|c|c|c|c|}
\hline $\begin{array}{l}\text { Temper- } \\
\text { ature }\end{array}$ & $\underset{\text { bars }}{\text { Pressure }} \stackrel{\text { Wavelength }}{A}$ & 6678.149 & 6438.4696 & 5875.618 & 5085.82 & 5015.675 & 4921.929 & 4799.92 & 4678.16 & $\begin{array}{l}\text { Specific } \\
\text { volume }\end{array}$ \\
\hline $\begin{array}{c}{ }^{\circ} \mathrm{C} \\
24.80\end{array}$ & $\begin{array}{r}1 \\
259.6 \\
463.6 \\
762.8 \\
1108.6\end{array}$ & $\begin{array}{l}1.33077 \\
1.33438 \\
1.33714 \\
1.34106 \\
1.34521\end{array}$ & $\begin{array}{l}1.33136 \\
1.33499 \\
1.33780 \\
1.34163 \\
1.34581\end{array}$ & $\begin{array}{l}1.33293 \\
1.33653 \\
1.33943 \\
1.34322 \\
1.34748\end{array}$ & $\begin{array}{l}1.33591 \\
1.33953 \\
1.34240 \\
1.34630 \\
1.35053\end{array}$ & $\begin{array}{l}1.33624 \\
1.33987 \\
1.34278 \\
1.34660 \\
1.35085\end{array}$ & $\begin{array}{l}1.33670 \\
1.34030 \\
1.34324 \\
1.34710 \\
1.35133\end{array}$ & $\begin{array}{l}1.33734 \\
1.34096 \\
1.34389 \\
1.34778 \\
1.35201\end{array}$ & $\begin{array}{l}1.33802 \\
1.34167 \\
1.34458 \\
1.34846 \\
1.35271\end{array}$ & $\begin{array}{c}m l / g \\
1.00288 \\
0.99152 \\
.98318 \\
.97180 \\
.95973\end{array}$ \\
\hline 34.50 & $\begin{array}{c}1 \\
259.3 \\
480.9 \\
799.2 \\
1110.0\end{array}$ & $\begin{array}{l}1.32963 \\
1.33319 \\
1.33614 \\
1.34007 \\
1.31367\end{array}$ & $\begin{array}{l}1.33020 \\
1.33375 \\
1.33679 \\
1.34069 \\
1.34429\end{array}$ & $\begin{array}{l}1.33177 \\
1.33531 \\
1.33832 \\
1.34228 \\
1.34589\end{array}$ & $\begin{array}{l}1.33474 \\
1.33830 \\
1.34132 \\
1.34537 \\
1.34897\end{array}$ & $\begin{array}{l}1.33506 \\
1.33865 \\
1.34163 \\
1.34567 \\
1.34928\end{array}$ & $\begin{array}{l}1.33552 \\
1.33908 \\
1.34213 \\
1.34613 \\
1.34974\end{array}$ & $\begin{array}{l}1.33615 \\
1.33974 \\
1.34274 \\
1.34676 \\
1.35042\end{array}$ & $\begin{array}{l}1.33683 \\
1.34043 \\
1.34344 \\
1.34747 \\
1.35116\end{array}$ & $\begin{array}{r}1.00580 \\
0.99463 \\
.98572 \\
.97385 \\
.96318\end{array}$ \\
\hline 54.34 & $\begin{array}{r}1 \\
241.6 \\
489.7 \\
785.1 \\
1127.7\end{array}$ & $\begin{array}{l}1.32655 \\
1.32985 \\
1.33307 \\
1.33667 \\
1.34053\end{array}$ & $\begin{array}{l}1.32712 \\
1.33043 \\
1.33361 \\
1.33725 \\
1.34116\end{array}$ & $\begin{array}{l}1.32866 \\
1.33192 \\
1.33518 \\
1.33883 \\
1.34274\end{array}$ & $\begin{array}{l}\text { 1. } 33159 \\
1.33490 \\
1.33813 \\
1.34184 \\
1.34577\end{array}$ & $\begin{array}{l}\text { 1. } 33191 \\
1.33523 \\
1.33849 \\
1.34216 \\
1.34609\end{array}$ & $\begin{array}{l}1.33236 \\
1.33567 \\
1.33893 \\
1.34258 \\
1.34656\end{array}$ & $\begin{array}{l}1.33299 \\
1.33633 \\
1.33960 \\
1.34327 \\
1.34718\end{array}$ & $\begin{array}{l}1.33366 \\
1.33698 \\
1.34028 \\
1.34396 \\
1.34791\end{array}$ & $\begin{array}{r}1.01415 \\
0.00372 \\
0.99371 \\
.98267 \\
.97089\end{array}$ \\
\hline 1.56 & $\begin{array}{r}1 \\
269.5 \\
507.4 \\
768.5 \\
1049.7\end{array}$ & $\begin{array}{l}1.33220 \\
1.33635 \\
1.33989 \\
1.34350 \\
1.34721\end{array}$ & $\begin{array}{l}1.33279 \\
1.33697 \\
1.34047 \\
1.34415 \\
1.34785\end{array}$ & $\begin{array}{l}\text { 1. } 33438 \\
\text { 1. } 33857 \\
1.34212 \\
1.34579 \\
1.34947\end{array}$ & $\begin{array}{l}\text { 1. } 33739 \\
1.34161 \\
1.34517 \\
1.34887 \\
1.35255\end{array}$ & $\begin{array}{l}1.33772 \\
1.34197 \\
1.34552 \\
1.34923 \\
1.35296\end{array}$ & $\begin{array}{l}1.33832 \\
1.34254 \\
1.34615 \\
1.34985 \\
1.35359\end{array}$ & $\begin{array}{l}1.33882 \\
1.34305 \\
1.34663 \\
1.35034 \\
1.35408\end{array}$ & $\begin{array}{l}1.33951 \\
1.34374 \\
1.34734 \\
1.35106 \\
1.35479\end{array}$ & $\begin{array}{r}1.00004 \\
0.98712 \\
.97662 \\
.96577 \\
.95522\end{array}$ \\
\hline 7.64 & $\begin{array}{c}1 \\
256.1 \\
497.8 \\
730.7 \\
1088.9\end{array}$ & $\begin{array}{l}1.33204 \\
1.33586 \\
1.33940 \\
1.34267 \\
1.3^{\Delta} 698\end{array}$ & $\begin{array}{l}1.33263 \\
1.33645 \\
1.34002 \\
1.34324 \\
1.34764\end{array}$ & $\begin{array}{l}1.33422 \\
1.33804 \\
1.34160 \\
\text { 1. } 34494 \\
1.34928\end{array}$ & $\begin{array}{l}1.33724 \\
1.34108 \\
1.34466 \\
1.34801 \\
1.35243\end{array}$ & $\begin{array}{l}1.33757 \\
1.34139 \\
1.34502 \\
1.34828 \\
1.35273\end{array}$ & $\begin{array}{l}1.33803 \\
1.34186 \\
1.34544 \\
1.34877 \\
1.35318\end{array}$ & $\begin{array}{l}1.33867 \\
1.34252 \\
1.34614 \\
1.34944 \\
1.35391\end{array}$ & $\begin{array}{l}1.33935 \\
1.34325 \\
1.34688 \\
1.35073 \\
1.35462\end{array}$ & $\begin{array}{r}1.00011 \\
0.98820 \\
.97788 \\
.96853 \\
.95682\end{array}$ \\
\hline
\end{tabular}

It will be noted in tables $1-3$ that the behavior at each wavelength is similar to that reported earlier for observations using the helium yellow line, i.e., index increases with increasing pressure and decreases with increasing temperature. In addition it can be noted that in all cases the change in index with pressure is greater in the violet end of the spectrum than in the red end with the effect of wavelength being much smaller in water than in the organic liquids. There is some indication that the effect of wavelength is greater at higher temperatures for all three liquids. These results will be discussed in detail later.

\section{Discussion}

The data given in tables 1 through 3 can be analyzed by various methods. The obvious treatment is by one of the well-known dispersion relationships. From quantum mechanical considerations of the interaction between radiation and matter Kramers and Heisenberg have derived the equation

$$
\mu^{2}-1=\sum_{i} \frac{e^{2} f_{i} N_{i}}{m \pi\left(\nu_{i}^{2}-\nu^{2}\right)}
$$

where $\mu$ is the index of radiation of frequency $\nu$, $N_{i}$ the number of oscillators per unit volume, $f_{i}$ the oscillator strength and $e$ and $m$ the charge and rest mass of the electron. This relationship takes the same form as the older, classical relationship developed by Drude where the optical electrons were regarded as being quasi-elastically bound to the nucleus. Despite the formal similarity of the two equations, the interpretation for $\nu_{i}$ in each case is different. In the Drude formulation the $\nu_{i}$ represent resonance frequencies of different electrons with different binding energies. In the Kramers-Heisenberg treatment the $\nu_{i}$ are values of the transition frequencies between states for the electronic system.

When an electric field at optical frequencies is applied to a dielectric the effective field which acts upon a given oscillator at the interior of the medium consists of the applied field plus the field created by the surrounding dipoles. In the usual derivation of the Drude formula no specific value is assigned to this polarization field, but Krishnan and Roy [5] have pointed out that the $\nu_{i}^{\prime}$ 's, the fundamental absorption frequencies of the medium include the effect of the polarization field. On the other hand, according to the well-known Lorentz-Loren z formula, the polarization field for a medium having cubic symmetry (or completely random symmetry as in a liquid) has been calculated to have the value (4/3) $\pi P$ where $P$ is the polarization of the medium. Accepting this calculation the Lorentz-Lorenz equation has the form

$$
\frac{\mu^{2}-1}{\mu^{2}+2}=\sum_{i} \frac{e^{2}}{3 m \pi} \frac{f_{i} N_{i}}{\left(\Omega_{i}^{2}-\nu^{2}\right)}
$$

where the characteristic frequencies, the $\Omega_{i}$ 's that appear, correspond to those of isolated oscillators unaffected by the polarization field.

Thus the Drude and the Lorentz-Lorenz equations are alternative formulas for the refractive index of a dense medium as a function of the frequency, the effect of the polarization field being taken into account in each equation in a different way. In order to visualize the effect of intermolecular interactions, it was decided to try to fit the experimental data to each of these dispersion formulas. 


\subsection{Benzene and Carbon Tetrachloride}

If only a single term of an equation of the Drude type is used, the equation can be transformed into the following linear form

$$
\frac{1}{\mu^{2}-1}=\frac{1}{A}\left(\nu_{0}^{2}-\nu^{2}\right)
$$

where $\nu_{0}$ is the absorption frequency and $\nu$, the frequency at which $\mu$ applies; the factors other than $\left(\nu^{2}-\nu^{2}\right)$ which appear in eq 2 have been designated by $A$. Using the measured values of $\mu$ and the known frequencies it was found that for both benzene and carbon tetrachloride eq (4) satisfactorily represented the data with a residual standard deviation of $1 /\left(\mu^{2}-1\right)$ of about $1 \times 10^{-4}$ based on $6 \mathrm{deg}$ of freedom. The curve fitting which was done on the computer yielded the values for the constants of eq (4) shown in tables 4 and 5 for benzene and carbon tetrachloride.

TABLE 4.-Parameters of the Drude dispersion equation for benzene

\begin{tabular}{|c|c|c|c|c|c|c|}
\hline $\begin{array}{l}\text { Tem- } \\
\text { perature }\end{array}$ & $\begin{array}{c}\text { Pressure } \\
\text { bars }\end{array}$ & $\begin{array}{l}\text { Specific } \\
\text { volume }\end{array}$ & $\begin{array}{c}A \\
\mathrm{x} 10^{-31} \\
{[\text { cycles/ }} \\
\text { sec }]^{2}\end{array}$ & 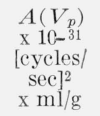 & $\begin{array}{c}\text { Funda- } \\
\text { mental } \\
\text { frequency, } \\
\nu_{0} \times 10^{-15}\end{array}$ & $\begin{array}{l}\text { Funda- } \\
\text { mental } \\
\text { wave- } \\
\text { length, } \lambda_{0}\end{array}$ \\
\hline${ }^{\circ} \mathrm{C}$ & $\begin{array}{c}1 \\
250.1 \\
489.0 \\
666.1\end{array}$ & $\begin{array}{c}m l / g \\
1.14433 \\
1.11973 \\
1.10057 \\
1.08828\end{array}$ & $\begin{array}{r}0.543360 \\
.555574 \\
.565792 \\
.572260\end{array}$ & $\begin{array}{r}0.621783 \\
.622093 \\
.622694 \\
.622779\end{array}$ & $\begin{array}{c}c / s \\
2.1498 \\
2.1441 \\
2.1399 \\
2.1371\end{array}$ & $\begin{array}{c}\AA \\
1394.6 \\
1398.2 \\
1401.0 \\
1402.8\end{array}$ \\
\hline 34.50 & $\begin{array}{r}1 \\
246.2 \\
484.8 \\
757.2 \\
1107.7\end{array}$ & $\begin{array}{l}1.15805 \\
1.13187 \\
1.11138 \\
1.09192 \\
1.07112\end{array}$ & $\begin{array}{l}.537099 \\
.549012 \\
.561588 \\
.571678 \\
.581631\end{array}$ & $\begin{array}{l}.621987 \\
.621410 \\
.624138 \\
.624227 \\
.622997\end{array}$ & $\begin{array}{l}2.1537 \\
2.1463 \\
2.1451 \\
2.1402 \\
2.1329\end{array}$ & $\begin{array}{l}1392.0 \\
1396.8 \\
1397.6 \\
1400.8 \\
1405.6\end{array}$ \\
\hline 54.34 & $\begin{array}{r}1 \\
274.5 \\
484.4 \\
770.2 \\
1124.5\end{array}$ & $\begin{array}{l}1.18757 \\
1.15350 \\
1.13305 \\
1.11014 \\
1.08705\end{array}$ & $\begin{array}{l}.522458 \\
.538693 \\
.547908 \\
.559951 \\
.571543\end{array}$ & $\begin{array}{l}.620455 \\
.621382 \\
.620807 \\
.621624 \\
.621296\end{array}$ & $\begin{array}{l}2.1583 \\
2.1517 \\
2.1455 \\
2.1413 \\
2.1349\end{array}$ & $\begin{array}{l}1389.0 \\
1393.3 \\
1397.3 \\
1400.1 \\
1404.2\end{array}$ \\
\hline
\end{tabular}

TABLE 5. Parameters of the Drude dispersion equation for carbon tetrachloride

\begin{tabular}{|c|c|c|c|c|c|c|}
\hline $\begin{array}{l}\text { Tem- } \\
\text { perature }\end{array}$ & $\begin{array}{c}\text { Pressure } \\
\text { bars }\end{array}$ & $\begin{array}{l}\text { Specific } \\
\text { volume }\end{array}$ & $\begin{array}{c}A \\
\times 10^{-31} \\
{[\text { cycles/ }} \\
\text { sec }]^{2}\end{array}$ & $\begin{array}{c}A\left(V_{p}\right) \\
\times 10^{-31} \\
{[\mathrm{cycles} /} \\
\left.\mathrm{sec}^{2}\right]^{2} \\
\times \mathrm{ml} / \mathrm{g}\end{array}$ & $\begin{array}{c}\text { Funda- } \\
\text { mental } \\
\text { frequency, } \\
\nu_{0} \times 10^{-15}\end{array}$ & $\begin{array}{c}\text { Funda- } \\
\text { mental } \\
\text { wave- } \\
\text { length, } \lambda_{0}\end{array}$ \\
\hline${ }^{\circ} \mathrm{C}$ & $\begin{array}{r}1 \\
276.9 \\
523.6 \\
797.4 \\
1116.7\end{array}$ & $\begin{array}{c}m l / g \\
0.630927 \\
.614859 \\
.603465 \\
.592991 \\
.582760\end{array}$ & $\begin{array}{r}0.79919 \\
.81931 \\
.83860 \\
.85571 \\
.86741\end{array}$ & $\begin{array}{r}0.50423 \\
.50376 \\
.50607 \\
.50743 \\
.50549\end{array}$ & $\begin{array}{c}c / s \\
2.7131 \\
2.7022 \\
2.7015 \\
2.6991 \\
2.6879\end{array}$ & $\begin{array}{c}\text { A } \\
1105.0 \\
1109.4 \\
1109.7 \\
1110.7 \\
1115.3\end{array}$ \\
\hline 34.50 & $\begin{array}{r}1 \\
255.4 \\
480.9 \\
756.1 \\
1119.9\end{array}$ & $\begin{array}{l}.638553 \\
.622336 \\
.610937 \\
.599476 \\
.587098\end{array}$ & $\begin{array}{l}.78865 \\
.81091 \\
.82840 \\
.83943 \\
.85388\end{array}$ & $\begin{array}{l}.50359 \\
.50466 \\
.50610 \\
.50322 \\
.50131\end{array}$ & $\begin{array}{l}2.7159 \\
2.7089 \\
2.7055 \\
2.6918 \\
2.6802\end{array}$ & $\begin{array}{l}1103.8 \\
1106.7 \\
1108.1 \\
1113.7 \\
1118.5\end{array}$ \\
\hline 54. 34 & $\begin{array}{r}1 \\
248.7 \\
452.7 \\
751.9 \\
1059.2\end{array}$ & $\begin{array}{l}.654959 \\
.636227 \\
.624227 \\
.610069 \\
.598302\end{array}$ & $\begin{array}{l}.76030 \\
.78591 \\
.79956 \\
.82203 \\
.83820\end{array}$ & $\begin{array}{l}.49797 \\
.50002 \\
.49911 \\
.50149 \\
.50150\end{array}$ & $\begin{array}{l}2.7072 \\
2.7012 \\
2.6922 \\
2.6893 \\
2.6822\end{array}$ & $\begin{array}{l}1107.4 \\
1109.9 \\
1113.6 \\
1114.8 \\
1117.7\end{array}$ \\
\hline
\end{tabular}

The derived value of the constant, $A$ will vary with the density through its dependence on $N$. If it is assumed that $A\left(V_{p}\right)$ is constant where $V_{p}$ is specific volume, then the density dependence can be eliminated and the values so obtained are given in column 5 of the tables. It can be observed from these values that there is no apparent systematic trend with either $P$ or $T$. Because the lack of such a trend means that the oscillator strength is constant within the limits of error of the evaluation, it seems reasonable to assume that the oscillator strength is, in fact, constant. On the other hand the values of $\nu_{\mathrm{o}}$, the absorption frequency, derived from eq (4) and given in column 6 show a systematic shift to lower frequencies with increasing pressure. The values of the absorption frequencies derived are in the region where absorption is to be expected [6] and the shift with pressure is of the order of $10 \AA / \mathrm{kb}$. However, this rate of shift is approximately twice the value observed by Oksengorn [7] for the benzene band in the region of $2500 \AA$ although it is in the same direction. There do not appear to be data available for carbon tetrachloride for shifts with pressure.

From these findings it is apparent that the change of index with pressure can be described quantitatively by an equation of the Drude type in which the oscillator strength remains constant, but the apparent absorption frequency shifts to longer wavelengths at higher pressure. By plotting the fundamental wavelengths derived from eq (4) against the specific volume, an attempt was made to find the effect upon the fundamental absorption wavelength due solely to temperature. These plots are shown for benzene and carbon tetrachloride in figures 2 and 3 . It was not found possible to evaluate the purely temperature effect in either case because of the scatter of the data. From the figures, however, it seems not unlikely that temperature effects of a small order of magnitude exist. These effects are to be attributed to the changes in the local field due to interaction between neighboring molecules at constant density.

The data for benzene and carbon tetrachloride were also fitted to a single term equation of the Lorentz-Lorenz type by inserting into the following linear form.

$$
\frac{\mu^{2}+2}{\mu^{2}-1}=\frac{1}{B}\left(\Omega_{0}^{2}-\nu^{2}\right)
$$

where $\Omega_{0}$ is the fundamental absorption frequency of an isolated oscillator. The factors other than $\left(\Omega_{i}^{2}-\nu^{2}\right)$ which appear in eq (3) have been designated by $B$. The fittings were poorer than those obtained in using a single term Drude-type equation, because in each fitting of the data for a set of eight spectral lines the residual standard deviations of $\left(\mu^{2}+2\right) /$ $\left(\mu^{2}-1\right)$ varied from $2 \times 10^{-4}$ to $4 \times 10^{-4}$ for benzene and from $1 \times 10^{-4}$ to $4 \times 10^{-4}$ for carbon tetrachloride which deviations are outside the experimental error. The values of the constants appearing in eq (5) are given in tables 6 and 7 . In column 5 of these tables values of $B\left(V_{p}\right)$ are given, and it may be observed that there is no systematic trend with either $P$ or 


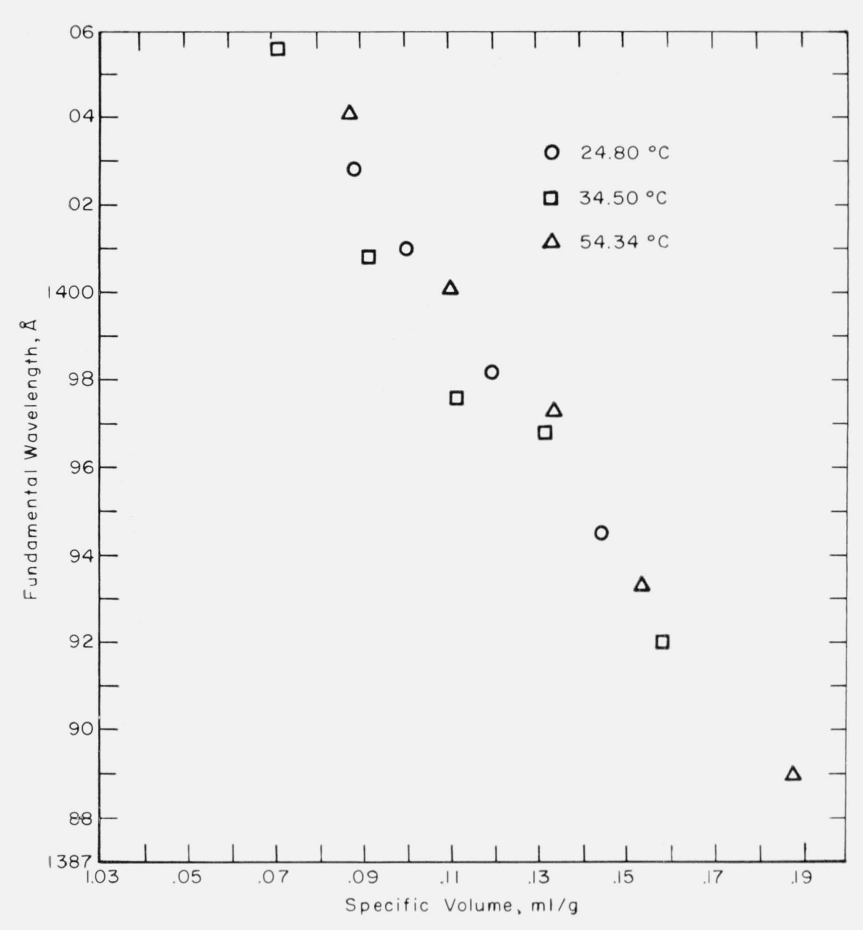

Figure 2. Fundamental wavelength versus specific volume for benzene at three different temperatures.

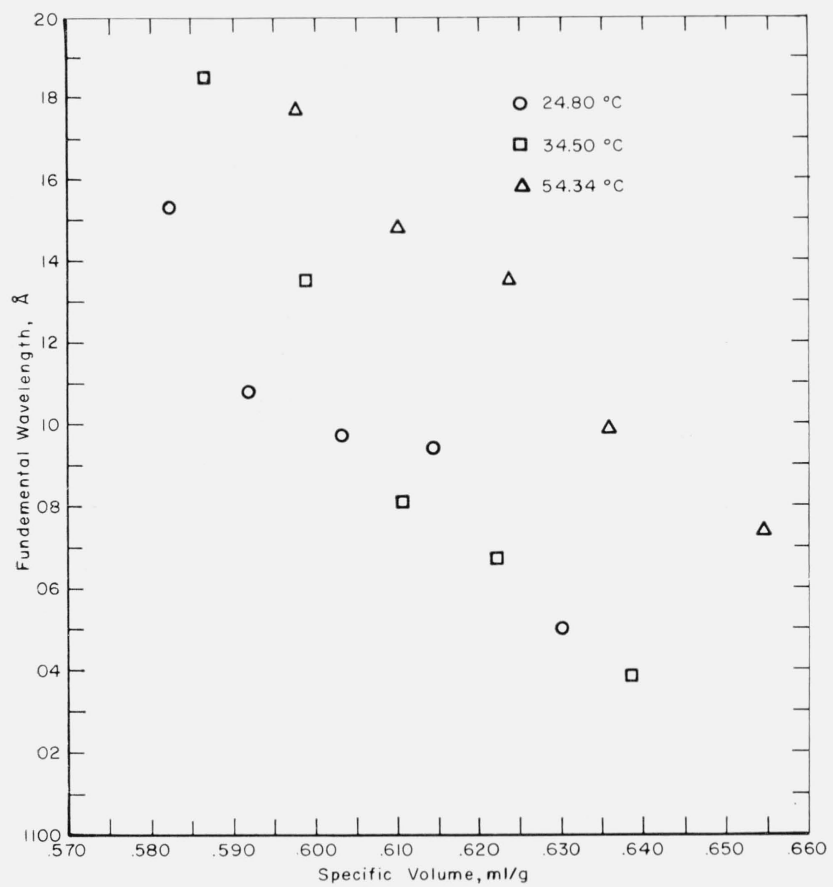

Figure 3. Fundamental wavelength versus specific volume for carbon tetrachloride at three different temperatures.
$T$ so that it may be inferred again that the oscillator strength is constant within the limits of error of the evaluation. Although there is some scatter in the results, it appears that the values of $\Omega_{0}$ given in column 6 show a trend toward higher frequencies with increasing pressure, in which case the shift is opposite in direction from that found earlier using a Drude-type equation.

TARLE 6. Parameters of the Lorentz-Lorenz dispersion equation for benzene

\begin{tabular}{|c|c|c|c|c|c|c|}
\hline $\begin{array}{l}\text { Tempera- } \\
\text { ture }\end{array}$ & $\begin{array}{c}\text { Pressure } \\
\text { bars }\end{array}$ & $\begin{array}{l}\text { Specific } \\
\text { volume }\end{array}$ & $\begin{array}{c}B \\
\times 10^{-31} \\
{[\text { cycles/ }} \\
\text { sec }]^{2}\end{array}$ & $\begin{array}{c}B\left(V_{p}\right) \\
\times 10^{-31} \\
{[\mathrm{cycles} / \mathrm{sec}]^{2}} \\
\times \mathrm{ml} / \mathrm{g}\end{array}$ & $\begin{array}{l}\text { Funda- } \\
\text { mental } \\
\text { frequeney, } \\
\Omega_{0} \times 10^{-15}\end{array}$ & $\begin{array}{c}\text { Funda- } \\
\text { mental } \\
\text { wavelength } \\
\lambda_{0}\end{array}$ \\
\hline $\begin{array}{r}{ }^{\circ} \mathrm{C} \\
24.80\end{array}$ & $\begin{array}{c}1 \\
250.1 \\
489.0 \\
666.1\end{array}$ & $\begin{array}{l}\mathrm{ml} / \mathrm{g} \\
\text { 1. } 14433 \\
\text { 1. } 11923 \\
\text { 1. } 10057 \\
\text { 1. } 08828\end{array}$ & $\begin{array}{r}0.181121 \\
.185191 \\
.188597 \\
.190755\end{array}$ & $\begin{array}{r}0.207262 \\
.207364 \\
.207564 \\
.207595\end{array}$ & $\begin{aligned} & c / s \\
& 2.5363 \\
& 2.5395 \\
& 2.5427 \\
& 2.5445\end{aligned}$ & $\begin{array}{c}\AA \\
1182.0 \\
1180.5 \\
1179.0 \\
1178.2\end{array}$ \\
\hline 34.50 & $\begin{array}{r}1 \\
246.2 \\
484.8 \\
757.2 \\
1107.7\end{array}$ & $\begin{array}{l}\text { 1. } 15805 \\
1.13187 \\
1.11138 \\
1.09192 \\
1.07112\end{array}$ & $\begin{array}{l}.179033 \\
.183004 \\
.187196 \\
.190559 \\
.193877\end{array}$ & $\begin{array}{l}.207329 \\
.207137 \\
.208046 \\
.208075 \\
.207666\end{array}$ & $\begin{array}{l}2.5355 \\
2.5371 \\
2.5442 \\
2.5468 \\
2.5472\end{array}$ & $\begin{array}{l}1182.4 \\
1181.6 \\
1178.3 \\
1177.1 \\
1177.0\end{array}$ \\
\hline 54.34 & $\begin{array}{r}1 \\
274.5 \\
484.4 \\
770.2 \\
1124.5\end{array}$ & $\begin{array}{l}\text { 1. } 18757 \\
\text { 1. } 15350 \\
\text { 1. } 13305 \\
\text { 1. } 11014 \\
\text { 1. } 08705\end{array}$ & $\begin{array}{l}.174153 \\
.179564 \\
.182636 \\
.186650 \\
.190514\end{array}$ & $\begin{array}{l}.206819 \\
.207127 \\
.206936 \\
.207208 \\
.207098\end{array}$ & $\begin{array}{l}2.5298 \\
2.5348 \\
2.5356 \\
2.5400 \\
2.5422\end{array}$ & $\begin{array}{l}1185.0 \\
1182.7 \\
1182.3 \\
1180.3 \\
1179.3\end{array}$ \\
\hline
\end{tabular}

TARLE 7.-Parameters of the Lorentz-Lorenz dispersion equation for carton tetrachloride

\begin{tabular}{|c|c|c|c|c|c|c|}
\hline $\begin{array}{l}\text { Tempera- } \\
\text { ture }\end{array}$ & $\begin{array}{c}\text { Pressure } \\
\text { bars }\end{array}$ & $\begin{array}{l}\text { Specific } \\
\text { volume }\end{array}$ & $\begin{array}{c}B \\
\text { x } 10^{-31} \\
{[\text { cycles/ }} \\
\text { sec }]^{2}\end{array}$ & $\begin{array}{c}B\left(V_{p}\right) \\
\times 10^{-31} \\
{[\mathrm{cycles} / \mathrm{sec}]^{2}} \\
\mathrm{x} \mathrm{ml} / \mathrm{g}\end{array}$ & $\begin{array}{l}\text { Funda- } \\
\text { mental } \\
\text { frequency, } \\
\Omega_{0} \times 10^{-15}\end{array}$ & $\begin{array}{c}\text { Funda- } \\
\text { mental } \\
\text { wavelength, } \\
\lambda_{0}\end{array}$ \\
\hline $\begin{array}{c}{ }^{\circ} \mathrm{C} \\
24.80\end{array}$ & $\begin{array}{r}1 \\
276.9 \\
523.6 \\
797.4 \\
1116.7\end{array}$ & $\begin{array}{l}\quad \mathrm{ml} / \mathrm{g} \\
.630927 \\
.614859 \\
.6003465 \\
.592991 \\
.582760\end{array}$ & $\begin{array}{l}.266398 \\
.273104 \\
.279532 \\
.285237 \\
.289136\end{array}$ & $\begin{array}{r}0.168078 \\
.167920 \\
.168688 \\
.169143 \\
.168497\end{array}$ & $\begin{array}{c}c / s \\
\text { 3. } 1662 \\
\text { 3. } 1675 \\
\text { 3. } 1771 \\
\text { 3. } 1840 \\
\text { 3. } 1806\end{array}$ & $\begin{array}{c}\text { A } \\
946.9 \\
946.7 \\
943.6 \\
941.6 \\
942.6\end{array}$ \\
\hline 34.50 & $\begin{array}{r}1 \\
255.4 \\
480.9 \\
756.1 \\
1119.9\end{array}$ & $\begin{array}{l}.639553 \\
.622336 \\
.610937 \\
.599476 \\
.587098\end{array}$ & $\begin{array}{l}.262884 \\
.270304 \\
.276132 \\
.279182 \\
284625\end{array}$ & $\begin{array}{l}.167865 \\
.168220 \\
.168699 \\
.167363 \\
.167103\end{array}$ & $\begin{array}{l}\text { 3. } 1631 \\
\text { 3. } 1688 \\
\text { 3. } 1750 \\
\text { 3. } 1692 \\
\text { 3. } 1670\end{array}$ & $\begin{array}{l}947.8 \\
946.1 \\
944.2 \\
946.0 \\
946.6\end{array}$ \\
\hline 54.34 & $\begin{array}{r}1 . \\
248.7 \\
452.7 \\
751.9 \\
1059.2\end{array}$ & $\begin{array}{l}.654959 \\
.636227 \\
.624227 \\
.610060 \\
.598302\end{array}$ & $\begin{array}{l}.253433 \\
261969 \\
.266519 \\
.274010 \\
.279401\end{array}$ & $\begin{array}{l}.165988 \\
.166772 \\
.166368 \\
.167163 \\
.167166\end{array}$ & $\begin{array}{l}3.1406 \\
3.1490 \\
3.1485 \\
3.1579 \\
3.1604\end{array}$ & $\begin{array}{l}954.6 \\
952.0 \\
952.2 \\
949.3 \\
948.6\end{array}$ \\
\hline
\end{tabular}

\subsection{Water}

A single term Drude-type dispersion equation will not fit the data for water within the experimental error, even though the dispersion for water is less than for the organic liquids. The results of the fitting processes showed that the residual standard deviations varied from $2 \times 10^{-4}$ to $3 \times 10^{-4}$. In order to obtain a satisfactory fit a second term was required involving an absorption in the infrared. This frequency and its shift with pressure and temperature was obtained from the data of Giguère and Harvey [8] and Fishman and Drikamer [9]. Using the two-term equation, the data were fitted to within the experimental error and the derived values are 
given in table 8 . In contrast with the results obtained for benzene and carbon tetrachloride there is no systematic trend in the absorption frequency, and there appears to be a random fluctuation in the derived values. The effect of pressure on dispersion is much smaller than in the organic liquids and apparently the effect is lost by internal compensation in the curve fitting process.

TABLE 8. Parameters of the Drude dispersion equation for water

\begin{tabular}{|c|c|c|c|c|c|c|}
\hline $\begin{array}{c}\text { Tem- } \\
\text { perature }\end{array}$ & $\begin{array}{c}\text { Pressure } \\
\text { bars }\end{array}$ & $\begin{array}{l}\text { Specific } \\
\text { volume }\end{array}$ & $\begin{array}{c}A \\
\times 10^{-31} \\
\text { [cycles/ } \\
\text { sec] }{ }^{2}\end{array}$ & $\begin{array}{c}A\left(\boldsymbol{V}_{p}\right) \\
\times 10^{-31} \\
\text { [cycles] } \\
\text { sec] }{ }^{2} \\
\times \mathrm{ml} / \mathrm{g}\end{array}$ & $\begin{array}{c}\text { Funda- } \\
\text { mental } \\
\text { frequency, } \nu_{0} \\
\times 10^{-15}\end{array}$ & $\begin{array}{c}\text { Funda- } \\
\text { mental } \\
\text { wave- } \\
\text { length, } \lambda_{0}\end{array}$ \\
\hline 24.80 & $\begin{array}{c}1 \\
259.6 \\
463.6 \\
762.8 \\
1108.6\end{array}$ & $\begin{array}{c}m l / g \\
1.00288 \\
0.99152 \\
.98318 \\
.97180 \\
.95973\end{array}$ & $\begin{array}{r}0.75220 \\
.75116 \\
.74886 \\
.76509 \\
.77690\end{array}$ & $\begin{array}{r}0.75437 \\
.74479 \\
.73626 \\
.74351 \\
.74561\end{array}$ & $\begin{array}{c}c / s \\
3.1293 \\
3.1278 \\
3.1086 \\
3.1215 \\
3.1235\end{array}$ & $\begin{array}{c}\stackrel{\circ}{A} \\
958.0 \\
958.5 \\
964.4 \\
960.4 \\
959.8\end{array}$ \\
\hline 34.50 & $\begin{array}{c}1 \\
259.3 \\
480.9 \\
799.2 \\
1110.0\end{array}$ & $\begin{array}{r}\text { 1. } 00580 \\
0.99463 \\
.98572 \\
.97385 \\
.96318\end{array}$ & $\begin{array}{l}.73536 \\
.74742 \\
.75922 \\
.76336 \\
.77383\end{array}$ & $\begin{array}{l}.73963 \\
.74341 \\
.74838 \\
.74340 \\
.74534\end{array}$ & $\begin{array}{l}\text { 3. } 1204 \\
\text { 3. } 1265 \\
\text { 3. } 1349 \\
3.2290 \\
\text { 3. } 1253\end{array}$ & $\begin{array}{l}960.8 \\
958.9 \\
956.3 \\
960.0 \\
959.2\end{array}$ \\
\hline 54.34 & $\begin{array}{c}1 \\
241.6 \\
489.7 \\
785.1 \\
1127.7\end{array}$ & $\begin{array}{l}1.01415 \\
1.00372 \\
0.99371 \\
.98267 \\
.97089\end{array}$ & $\begin{array}{l}.73179 \\
.74346 \\
.75017 \\
.76033 \\
.77127\end{array}$ & $\begin{array}{l}.74214 \\
.74623 \\
.74545 \\
.74715 \\
.74882\end{array}$ & $\begin{array}{l}\text { 3. } 1293 \\
\text { 3. } 1360 \\
\text { 3. } 1328 \\
\text { 3. } 1345 \\
\text { 3. } 1363\end{array}$ & $\begin{array}{l}958.0 \\
956.0 \\
956.9 \\
955.4 \\
955.9\end{array}$ \\
\hline
\end{tabular}

Likewise, it was not found possible to fit the data for water to a single term equation of the LorentzLorenz type; the residual standard deviations were found to vary from $6 \times 10^{-4}$ to $10 \times 10^{-4}$. No attempt was made to fit the data to a Lorentz-Lorenz equation with two terms. Krishnan and Roy [5] have pointed out that the fundamental frequencies, the $\nu_{i}$ 's that appear in the Drude equation are the experimentally observed absorption bands, and, although it would have been possible to take the data of Giguère and Harvey [8] and Fishman and Drikamer [9] and convert the $\nu_{i}{ }^{\prime}$ S to the $\Omega_{i}{ }^{\prime}$ s of the Lorentz-Lorenz equation, it appeared that the results would be too tenuous. The data on water can be considered from a somewhat different viewpoint as follows:

Many of the abnormalities of liquid water can be rationalized by the concept initially advanced by Röntgen [10] that water could be considered as a mixture of molecules of different degrees of association. In its simplest form this concept considers two types of water molecules, one having a greater density than the other with the relative proportions of the two types being influenced by temperature and pressure. The less dense form may be considered as analogous to the ice molecule which forms from water with an increase in volume. Many workers [11] have attempted to estimate the percentages of the types of molecules, but there is no agreement on either the size or percentage of the various species as the temperature is varied. It is generally accepted that the relative proportion of the less dense icelike molecules decreases with increasing temperature [11, 12]. Bridgman [13] from studies of viscosity at elevated pressure and Tammann from
PV'T data on water [14] concluded that the proportion of the less dense species also decreased with increasing pressure. Insofar as the index of refraction is concerned, there is no anomaly at the maximum density point and it is possible to regard the index of water as arising from the indices of its components using certain assumptions regarding the refractivity of the components [see Chéneveau, 12]. Such computations have been made with the present data and produce results in general agreement with those of previous workers [11, 12]. These data will not be reproduced here. It will suffice to note that, as shown earlier, for the wavelength of the helium yellow line [see reference 1, fig. 4] a plot of index against specific volume for water shows that the data separate into definite isotherms. At a constant specific volume the decrease in index with rising temperature is in full accord with the concept that there is a decrease in the relative proportion of the less dense molecules which have the higher refractivity.

\subsection{Theoretical Considerations}

These data on index of refraction are suitable for an analysis of the type proposed by Ramachandran $[15,16]$ who studied the thermo-optic behavior of solids. He assumed that the oscillator strength is invariant with changes in density and temperature, an assumption verified in part by the data of tables 4,5 , and 8 for the liquids studied here. He attributes the change in index with changing temperature to, partly, a change in the number of oscillators per unit volume (density effect) and partly a change in the absorption frequency arising from either change in density or change in temperature.

The data may be treated in a simpler manner and more analytically according to the method of Ramachandran and Radhakrishnan [16, 17] where the analysis proceeds as follows: starting with a simplified Drude equation applicable to a single wavelength they divide $d \mu / d T$, the observed change in index with temperature into three parts defined as (1) the change due to the number of oscillators per unit volume, (2) the change in polarizability of the oscillators arising from the change in density and (3) the change in polarizability due solely to the temperature change. Denoting these by $P, Q$, and $R$ respectively they deduce the following values.

$$
\begin{gathered}
P=-\gamma\left(\frac{\mu^{2}-1}{2 \mu}\right) \\
Q=-\gamma\left[\rho\left(\frac{d \mu}{d \rho}\right)-\frac{\mu^{2}-1}{2 \mu}\right] \\
R=d \mu / d T+\gamma \rho(d \mu / d \rho)
\end{gathered}
$$

where $\rho$ is the density, $\mu$ the index, $T$ the temperature and

$$
\gamma=-\frac{1}{\rho} \frac{d \rho}{d T} \text { and } d \mu / d T=P+Q+R
$$


In figures 4,5 , and 6 values of $\left(\mu^{2}-1\right) / \rho$ for the three liquids are given as a function of wavelength at $34.50{ }^{\circ} \mathrm{C}$. This temperature was chosen because of the fact that the pressure range for benzene at $24.80{ }^{\circ} \mathrm{C}$ is limited by the freezing of benzene. The fact that the curves do not coincide for any of the liquids is indicative of the fact that the polarization field has changed due to the change in intermolecular spacing at the elevated pressures. The fact that the values for the higher pressures always are above the values at one bar can be explained by the fact that the increase in density brings about an increase in the strength of the polarization field acting upon an individual scattering center. The shift to longer wavelengths of the absorption frequency as the pressure increases in benzene and carbon tetrachloride is another manifestation of the same phenomenon. It is of interest to note that although no shift of absorption frequency could be detected in table 8 for water, figure 6 shows the same general picture for water as for the other liquids, the effect being much smaller with water. In fact, his discrepancy arises in part from the lower compressibility of water, but if comparisons are made for equal changes in volume it will be found that the separation of the curves for water is still much less than for benzene and carbon tetrachloride. The overall picture indicated by these figures can be obtained quantitatively by the use of eqs (6), (7), and (8). Such values are given in table 9 along with comparable values for cubic crystals $[16,17]$.

It will be noted that $P$, the purely density contribution, is much larger for the liquids than for most crystals. This is due largely to the fact that the expansivities of the liquids are larger than the crystals in most instances.

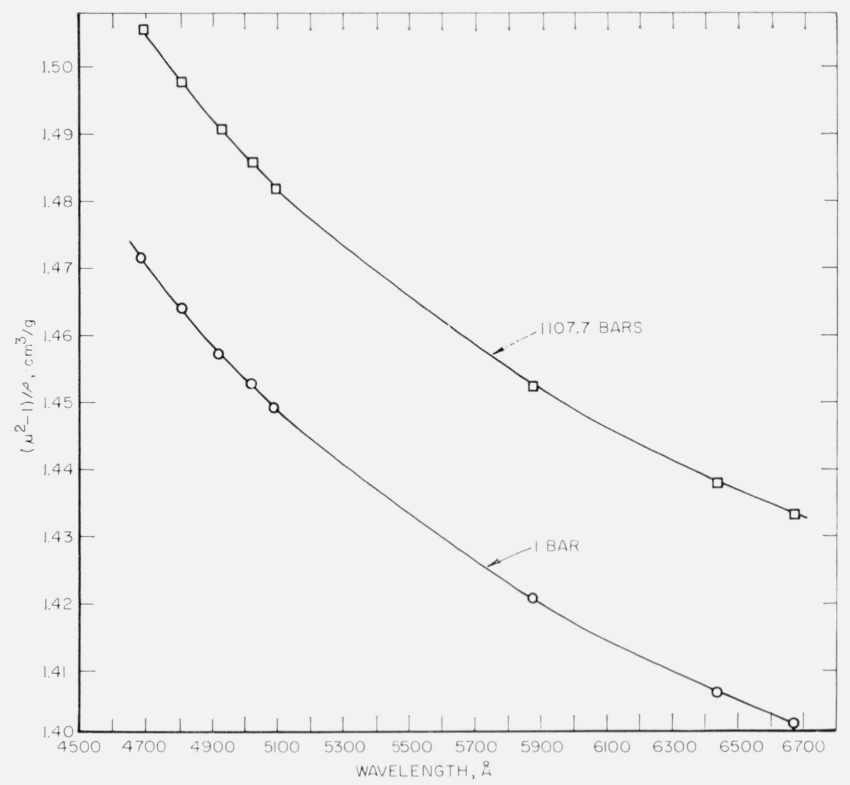

Figure 4. $\left(\mu^{2}-1\right) / \rho$ versus wavelength at one bar and an elevated pressure for benzene at $34.50{ }^{\circ} \mathrm{C}$.
$Q$ represents the change in refractive index arising from change in the polarizability of an oscillator which is brought about by change in volume. $Q$ must also include the change in the polarization field acting upon a given oscillator which is likewise induced by change in volume. $Q$ is opposite in sign for the liquids and the crystals. The values of $Q$ for benzene and carbon tetrachloride are much larger in absolute value than values of $Q$ for the solids, a fact probably due to the disparity in the values of the expansivities of liquid and solid. The value of $Q$ for water is inordinately low in comparison with the $Q$ values for the other two liquids. This observation may be explained by the fact that (1) the water is less compressible than the other two liquids, and there is a correspondingly smaller change in the local field, and (2) there is a smaller percentage of icelike molecules at higher pressures.

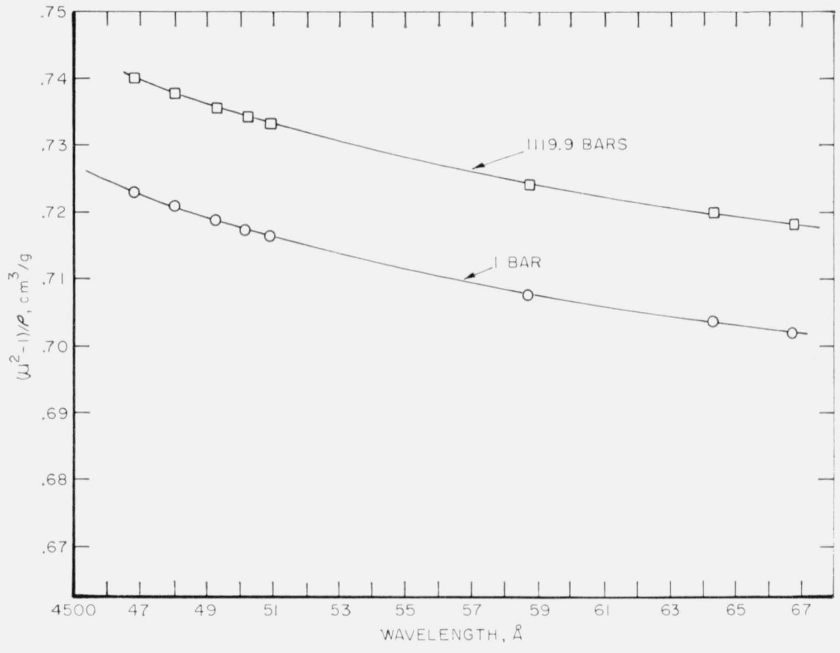

Figure 5. $\left(\mu^{2}-1\right) / \rho$ versus wavelength at one bar and an elevated pressure for carbon tetrachloride at $34.50{ }^{\circ} \mathrm{C}$.

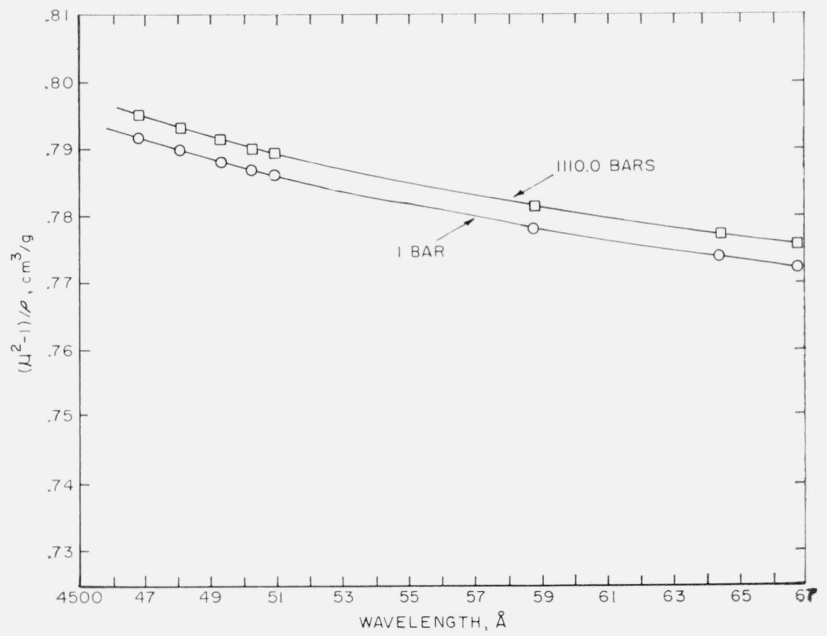

Figure 6. $\left(\mu^{2}-1\right) / \rho$ versus wavelength at one bar and an elevated pressure for water at $34.50{ }^{\circ} \mathrm{C}$. 
TABle 9. Values of $\gamma, P, Q$, and $R$ for crystals and liquids*

\begin{tabular}{|c|c|c|c|c|}
\hline Crystals & $\gamma \times 10^{5}$ & $P \times 10^{5}$ & $Q \times 10^{5}$ & $R \times 10^{5}$ \\
\hline $\begin{array}{c}\mathrm{LiF} \\
\mathrm{NaCl} \\
\mathrm{KCl} \\
\mathrm{KBr} \\
\mathrm{KI} \\
\mathrm{CaF}_{2} \\
\mathrm{MgO} \\
\text { Diamond }\end{array}$ & $\begin{array}{l}10.2 \\
12 \\
11.4 \\
12 \\
13.5 \\
5.7 \\
3.9 \\
1.3\end{array}$ & $\begin{array}{l}-3.4 \\
-5.4 \\
-4.7 \\
-5.6 \\
-7.2 \\
-2.1 \\
-2.2 \\
-1.3\end{array}$ & $\begin{array}{l}2.4 \\
2.5 \\
2.1 \\
1.4 \\
1.4 \\
0.7 \\
3.6 \\
1.66\end{array}$ & $\begin{array}{l}-0.3 \\
-0.9 \\
-1.0 \\
-0.2 \\
+0.8 \\
+0.2 \\
+0.2 \\
+0.6\end{array}$ \\
\hline Liquids & & & & \\
\hline $\begin{array}{r}\mathrm{C}_{6} \mathrm{H}_{6} \\
\mathrm{CCl}_{4} \\
\mathrm{H}_{2} \mathrm{O}\end{array}$ & $\begin{array}{r}122.1 \\
123.1 \\
25.2\end{array}$ & $\begin{array}{r}-50.8 \\
-47.5 \\
-7.4\end{array}$ & $\begin{array}{r}-14.4 \\
-13.6 \\
-0.6\end{array}$ & $\begin{array}{r}0 \\
4.1 \\
-2.4\end{array}$ \\
\hline
\end{tabular}

NoтE: The values for the crystals were derived from measurements made at $5893 \AA$ while measurements on the liquids were made at $5876 \AA$, but the differences ineurred are negligible.

*The data on crystals which are given in this table are taken from the book by R. S. Krishnan. See reference [16].

$R$ in table 9 represents the contribution to refractive index which may be attributed solely to temperature change. It has been found heretofore for crystals that $R$ may be of either sign and is usually two or three times smaller than $Q$ in absolute value. In accordance with these results $R$ is much less than $Q$ for carbon tetrachloride and $R$ was not measurable for benzene although it probably exists. For water, the high absolute value of $R$ in comparison with the absolute value of $Q$ is in keeping with the thought that at constant specific volume an increase in temperature causes a decrease in the proportion of icelike molecules with their high refractivity.

Some idea of the consistency of the data may be obtained as follows: a graph of index versus specific volume of water at one bar for the helium yellow line is given in figure 7 . The data used were reported by

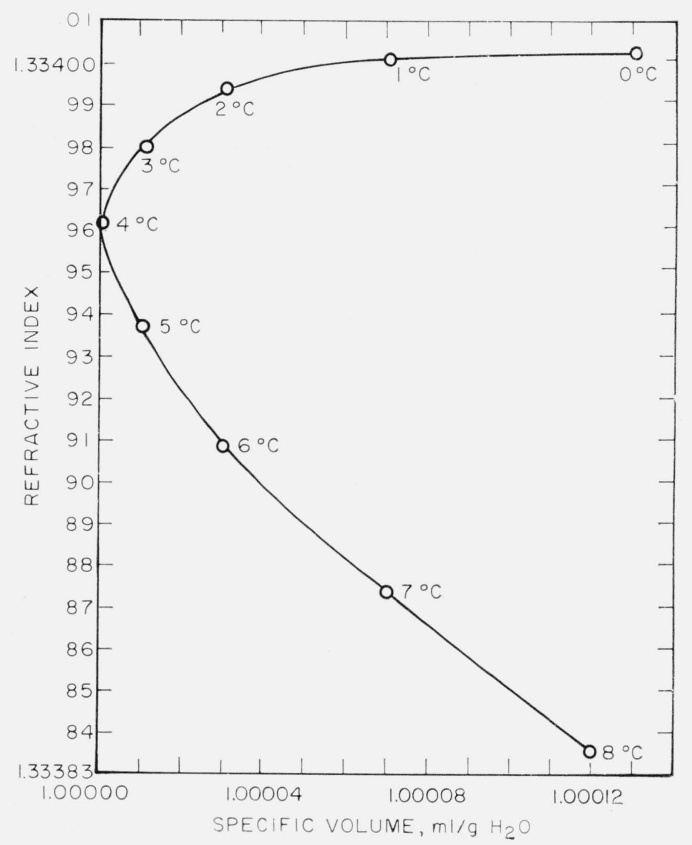

Figure 7. Refractive index versus specific volume for water in the vicinity of the maximum density point at a pressure of one bar.
Tilton [4]. At the specific volume of $1.00007 \mathrm{ml} / \mathrm{g}$, which occurs at $1{ }^{\circ} \mathrm{C}$ and $7^{\circ} \mathrm{C}$, the change in refractive index with temperature is found to be $\left(\mu_{1 \circ \mathrm{C}}-\mu_{7}{ }_{\circ \mathrm{C}}\right) / 6=2.18 \times 10^{-5} /{ }^{\circ} \mathrm{C}$. At the corresponding specific volume for the temperature interval $1.56{ }^{\circ} \mathrm{C}$ to $54.34{ }^{\circ} \mathrm{C}$. Where the specific volume is altered by compression [see ref. 1 , fig. 4] a value of $\left(\mu_{1.56{ }^{\circ} \mathrm{C}}-\right.$ $\left.\mu_{54.34}{ }^{\circ} \mathrm{C}\right) / 52.78=2.37 \times 10^{-5} /{ }^{\circ} \mathrm{C}$, is obtained. The agreement between these results indicates that the same phenomenon is responsible for the data in the two cases. It is of interest to note that in the case of water both $P$ and $Q$ are zero at $4{ }^{\circ} \mathrm{C}$ because $\gamma$ is zero at this temperature. Therefore, at $4{ }^{\circ} \mathrm{C}$ the quantity $R$ is the only contributing factor to the change in index. From the data of Tilton [4] the value of the change in index with temperature at $4{ }^{\circ} \mathrm{C}$ is ascertained to be $-2.1 \times 10^{-5} /{ }^{\circ} \mathrm{C}$. Similar values of $R$ based on the present data are at $1.56{ }^{\circ} \mathrm{C}$, $R=-2.1 \times 10^{-5} /{ }^{\circ} \mathrm{C}$; at $7.64{ }^{\circ} \mathrm{C}, R=-2.2 \times 10^{-5} /{ }^{\circ} \mathrm{C}$; and at $24.80{ }^{\circ} \mathrm{C}, R=-2.4 \times 10^{-5} /{ }^{\circ} \mathrm{C}$. The agreement between these data and the trends may be taken as indicative of the change in $R$ with temperature.

In figures 8,9 , and 10 , values of $\left(\mu^{2}-1\right) /\left(\mu^{2}+2\right) \rho$ for the three liquids are given as a function of wavelength at $34.50{ }^{\circ} \mathrm{C}$. In these plots the effect of density has been accounted for in dividing by the factor $\rho$. Moreover, it must be borne in mind that in the Lorentz-Lorenz treatment the polarization field is assigned the calculated value of $(4 / 3) \pi P$. The fact that the two curves do not coincide on each plot may best be explained by assuming that an increase of density decreases the polarizability of

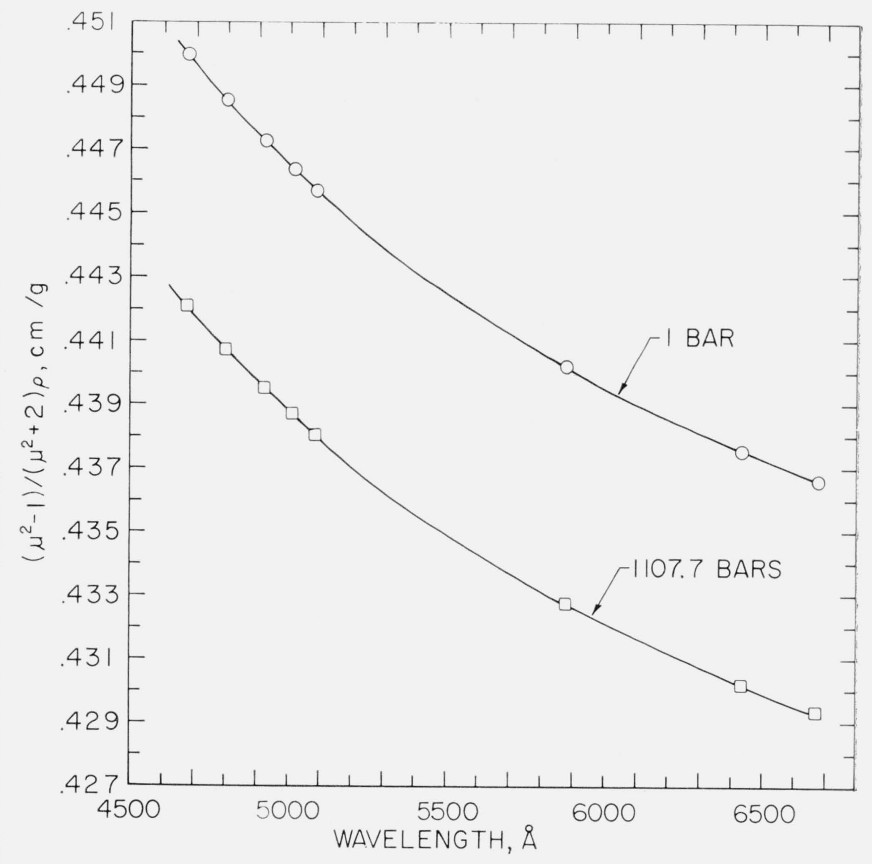

FiguRe 8. $\left(\mu^{2}-1\right) /\left(\mu^{2}+2\right) \rho$ versus wavelength at one bar and an elevated pressure for benzene at $34.50{ }^{\circ} \mathrm{C}$. 


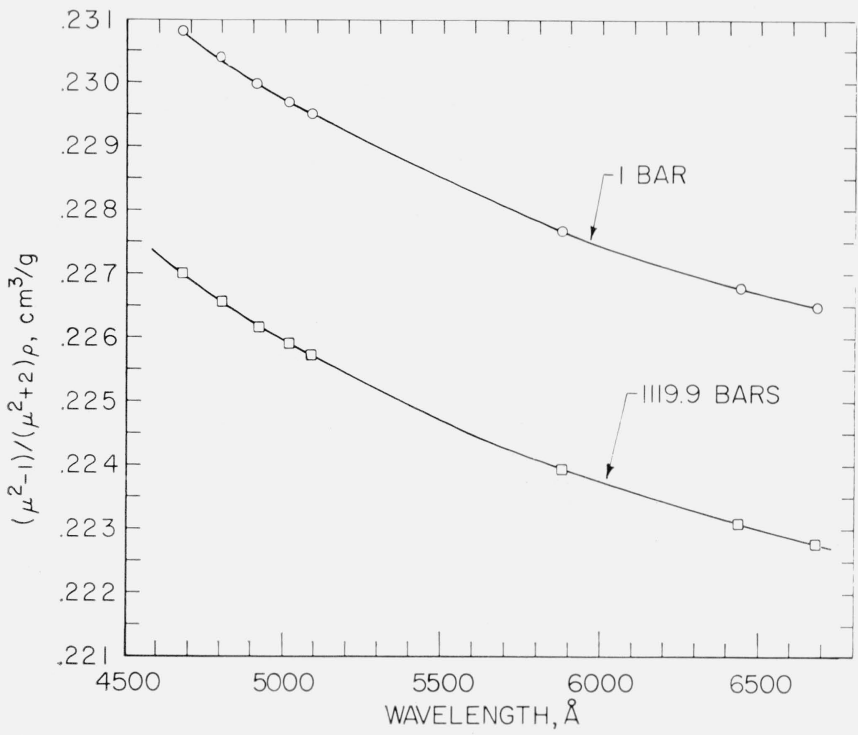

Figure 9. $\left(\mu^{2}-1\right) /\left(\mu^{2}+2\right) \rho$ versus wavelength at one bar and an elevated pressure for carbon tetrachloride at $34.50{ }^{\circ} \mathrm{C}$.

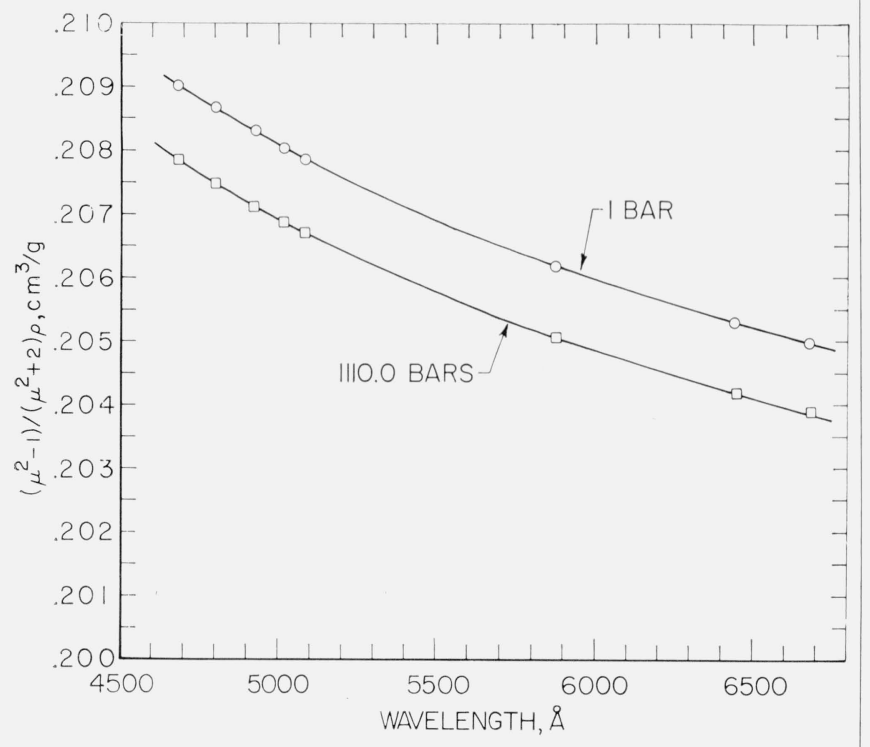

Figure 10. $\left(\mu^{2}-1\right) /\left(\mu^{2}+2\right) \rho$ versus wavelength at one bar and an elevated pressure for water at $34.50{ }^{\circ} \mathrm{C}$.

the molecules. This assumption is a generalization of the rules of Fajans and Joos [18]; it is well known that the refraction of ions decreases as the distance of nearest neighbors gets smaller. Further, the assumption is in accord with the work of Ten Seldam [19] who has shown that the quantum mechanical theory of the atom-in-box model leads to a polarizability which decreases with increasing pressure.

It is interesting to compare these results with the results of investigations on solids. Pockels [20] has shown that for optical glasses the use of the LorentzLorenz equation gives a considerably larger change of the index of refraction with density than do calculations made on the basis of photoelastic data. This discrepancy has also been noted in the study of crystals [21]. In fact for diamond [22] and $\mathrm{MgO}$ [23] the photoelastic data indicate that an increase in density results in an actual decrease in refractive index; i.e., in these crystals the contribution from decrease in polarizability of the ions must be even greater than the contribution from the increase in the number of ions per unit volume.

Mueller [24] has suggested that these changes in polarizability of solids are due to changes in energy levels and transition probabilities of optical electrons. Because the data for benzene and carbon tetrachloride indicate that the oscillator strengths (or transition probabilities) are constant within the limits of error of the evaluation, and because the fundamental absorption frequencies appear to show a trend toward higher values (see tables 6 and 7 ), it may be inferred that the failure of the curves to coincide in figures 8 and 9 is attributable essentially to changes in the energy levels, i.e., an increase in density creates a widening of the gap between the energy levels which determine the value of the fundamental absorption frequency.

In order to get a better understanding of the effect of density change at constant temperature in condensed phases one may compare an analysis of the data according to the Drude equation with an analysis according to the Lorentz-Lorenz equation, and then consider the situation both for the liquids studied here and for cubic crystals where data are available.

In figures 8, 9, and 10 (Lorentz-Lorenz equation) the curve representing the data at one bar lies above the curve for the data at an elevated pressure. The reverse of this order is shown by the curves in figures 4, 5, and 6 (Drude equation). In tables 6 and 7 (Lorentz-Lorenz equation) the fundamental absorption frequencies seem to show shifts towards higher values with increasing density; a shift in the opposite direction with increasing density appears to be the case in tables 4 and 5 (Drude equation).

In Table 9 (which represents an analysis according to Drude's equation but confined to one wavelength) the values of $Q$ for crystals are always positive while the $Q$ values for liquids ar e always negative. Burstein and Smith [21] have shown that for cubic crystals the experimentally determined change in refractive index is always smaller than the change calculated from either the Lorentz-Lorenz or Drude formulas.

From this evidence one might conclude that for both solids and liquids considered here a change in density produces two competing effects - a change in the polarization field and a change in the polarizability of the individual oscillator; in the liquids it is the first effect which is more important, while for the crystals the second effect is dominant. This situation is what one might reasonably expect considering the greater compressibility of the liquids. 
The authors are indebted to Mr. Irving Malitson of the Refractometry Section of the National Bureau of Standards for his measurements of the refractive indices of carbon tetrachloride at one atmosphere.

\section{References}

[1] R. M. Waxler and C. E. Weir, J. Research NBS 67A (Phys, and Chem.) No. 2, 163 (1963).

[2] J. B. Saunders, J. Research NBS 35, 157 (1945) RP1668.

[3] A. F. Forziati, J. Research NBS 44, 373 (1950) RP2085.

[4] L. W. Tilton and J. K. Taylor, J. Research NBS 20, 419 (1938) RP1085.

[5] K. S. Krishnan and S. K. Roy, Phil. Mag. 43, 1000 (1952).

[6] G. N. Lewis and M. Kasha, J. Am. Chem. Soc. 67-1, 994 (1945).

[7] B. Oksengorn, Compt. rend. 242, 2324 (1956).

[8] P. A. Giguère and K. B. Harvey, Canad. J. Chem. 34, 798 (1956).

[9] E. Fishman and H. G. Drickamer, J. Chem. Phys. 24, 548 (1956).

[10] W. C. Röntgen, Ann. d. Physik (Wied.) 45, 91 (1892).

[11] N. E. Dorsey, Properties of ordinary water-substance (Reinhold Publishing Corp., New York, 1940).
[12] M. C. Chéneveau, Compt. rend. 156, 1972 (1913).

[13] P. W. Bridgman, Proc. Am. Acad. Arts Sci. 61, 57 (1926).

[14] G. Tammann, Z. Physik. Chem. 84, 293 (1913); Z. anorg. Chem. 158, 1 (1926).

[15] G. N. Ramachandran, Proc. Indian Acad. Sci. A25, 266 (1947).

[16] R. S. Krishnan, Progress in Crystal Physics, Volume I (Interscience Publishers, New York, London, 1958).

[17] G. N. Ramachandran and T. Radhakrishnan, Phil. Mag. 43, 317 (1952).

[18] K. Fajans and G. Joos, Zeit. f. Physik. 23, 1 (1924).

[19] C. A. Ten Seldam, Energies and Polarizabilities of Compressed Atoms (Van Gorcum \& Co. N. Y., 1953).

[20] F. Pockels, Ann. d. Physik y, 745 (1902).

[21] E. Burstein and P. L. Smith, Proc. Indian Acad. Sci. A28, 377 (1948).

[22] G. N. Ramachandran, Proc. Indian Acad. Sci. A32, 171 (1950).

[23] E. Burstein, P. L. Smith, and B. Henvis, Phys. Rev. 73 , 1262 (1948).

[24] H. Mueller, Phys. Rev. 47, 947 (1935).

(Paper 68A5-295) 